International Journal of Clinical Therapeutics and Diagnosis (1JCTD)

ISSN 2332-2926

\title{
Picroside II Diminishes Oxidative Stress Induced By Cerebral Ischemic Injury In Rats
}

Wang $\mathrm{L}^{1 *}$, Lv W' $\mathrm{W}^{2}$, Rong $\mathrm{L}^{1}$, Liu G ${ }^{1}$

Research Article

${ }^{1}$ Department of Traditional Chinese medicine, Institute of Integrative Medicine, Affiliated Hospital of Qingdao, University Medical College, Qingdao 266003, China.

${ }^{2}$ Department of Cardiology, Peoples' Hospital of Zhucheng City, Weifang 262200, China.

\section{Abstract}

Objective: To optimize the therapeutic dose and time window of picrosede II in cerebral ischemic injury in rats by orthogonal test. Methods The forebrain ischemia model was established by a bilateral common carotid artery occlusion (BCCAO)

Method: Rats were randomly grouped according to orthogonal experimental design and treated by injecting picroside II intraperitonenally at different ischemic times with different doses. The concentration of lipid perioxide malondialdehyde (MDA) in serum and brain was determined by thiobarbituric acid assay. The activity of superoxide dismutase (SOD) in these samples was determined by xanthine oxidase assay.

Result: The optimized composition of the therapeutic dose and time window of picroside II in cerebral ischemic injury was (1) ischemia $1.5 \mathrm{~h}$ with $10 \mathrm{mg} / \mathrm{kg}$ body weight according to the concentration of MDA in serum and the brain tissue, (2) ischemia $1.5 \mathrm{~h}$ with $20 \mathrm{mg} /$ $\mathrm{kg}$ body weight according to the activity of SOD in serum and the brain tissue.

Conclusion: From the principle of lowest therapeutic dose with longest time window, the optimized composition of the therapeutic dose and time window of picroside II in cerebral ischemic injury is ischemia $1.5 \mathrm{~h}$ with $10-20 \mathrm{mg} / \mathrm{kg}$ body weight.

Key Words: Picroside II; Cerebral Ischemia; Therapeutic Dose; Time Window; SOD; MDA.

\section{*Corresponding Author:}

Lianqing Wang

Department of Traditional Chinese medicine, Institute of Integrative Medicine, Affiliated Hospital of Qingdao University Medical College, Qingdao 266003, China.

E-mail:15898877166@163.com

Received: December 04,2013

Accepted: December 18, 2013

Published: December 19, 2013

Citation: Wang L, Lv W, Rong L, Liu G (2013) Picroside II Diminishes Oxidative Stress Induced By Cerebral Ischemic Injury in Rats. Int J Clin Ther Diagn. 1(4), 27-31. doi: http://dx.doi.org/10.19070/2332-2926130006

Copyright: Wang $\mathbf{L}^{\odot} 2013$ This is an open-access article distributed under the terms of the Creative Commons Attribution License, which permits unrestricted use, distribution and reproduction in any medium, provided the original author and source are credited.

\section{Introduction}

Stoke is a major health problem and there is no effective treatment of the disease. Therefore, finding novel chemicals that can be used to treat stroke has been an intensive research area. Picroside II seems to be a promising compound, yet its utilization in particular, the dosage and time window of its application after stroke has not been optimized. In this study, we wanted to address this problem using Malondialdehyde (MDA) and superoxide dismutase (SOD) as two parameters. MDA, a lipid peroxidation product formed by reactions between free radicals and polyunsaturated fatty acids, can be measured to reflect the magnitude of oxidative stress [1]. The aldehyde of MDA can occur crosslinking reaction with the amino groups of phosphatidylserine in neuronal membrane phospholipids [2]. The lipid peroxidation of biomembrane and its lipid peroxide products can also implicate the protein in the membrane to result in oxidative damage and apoptosis[3,4]. The content of MDA can reflect the levels of the free radicals and lipid peroxidation in tissue [5,6]. When the level of oxygen free radicals (OFR) elevates, SOD can react with superoxide anion with the generation of hydrogen peroxide. And hydrogen peroxide $\left(\mathrm{H}_{2} \mathrm{O}_{2}\right)$ can turn into water under the effect of catalase and glutathione peroxidase to remove the OFR to protect cells from damage. Therefore, the level of SOD activity can reflect the ability of the body in clearing OFR $[7,8]$. Cell culture experiments confirmed that picroside II can reduce $\mathrm{H} 2 \mathrm{O} 2$-induced injury in PC12 cells and improve cell survival $[9,10,11]$. Animal experiments showed that picroside II, an active ingredient of traditional Chinese medicine, can also inhibit the expression of inflammatory factors and apoptosis in cerebral ischemic penumbra, thus improve the neurobehavioral functions in rats $[12,13,14]$. Our group dealt the rats with different doses of picroside II at different ischemic time, and the result showed that the optimized therapeutic dose and time window of picroside II in cerebral ischemia reperfusion injury was ischemia $1.5 \mathrm{~h}$ with $20 \mathrm{mg} / \mathrm{kg}$ body weight by intraperitoneal injection [15]. This study was designed to detect the MDA levels and SOD activity in blood and brain tissue to further explore the anti-oxidation effect and the optimal therapeutic dose and time window of picroside II in cerebral ischemic injury. 


\section{Materials and Methods}

\section{Animal models}

A total of 30 healthy adult male Wistar rats, specific pathogen free grade, weighting 230-250 g, were provided by Experimental Animal Center of Qingdao Drug Inspection Institute (SCXK (LU)20100010). All animals were placed in the laboratory for them to adapt to the environment for a week and allowed for free access to food and water in a temperature- $\left(23 \pm 2^{\circ} \mathrm{C}\right)$ and humidity-controlled room with natural illumination. Five rats were randomly selected as a sham surgery group and the rest 25 rats were subjected to forebrain ischemia by a bilateral common carotid artery occlusion (BCCAO) method [16]. Before stroke surgeries, all rats had fasted for $12 \mathrm{~h}$ and were anesthetized by injecting intraperitoneally $10 \%$ chloral hydrate $(0.3 \mathrm{ml} / \mathrm{kg})$ and fixed in supine position to conduct aseptic operation. Four rats died and 21 rats survived after the surgeries The 21 rats were randomly divided into control group $(n=5)$ and treatment group $(n=16)$.

\section{Grouping design}

Total of 16 rats in drug treatment group were included in the statistical range and grouped according to the orthogonal design of $\left[\mathrm{L}_{16}\left(4^{5}\right)\right]$ consisting of two impact factors with four impact levels (Table 1). The impact factor A was the therapeutic time window designed four levels: $1.0 \mathrm{~h}, 1.5 \mathrm{~h}, 2.0 \mathrm{~h}, 2.5 \mathrm{~h}$ after ischemia. The impact factor $\mathrm{B}$ is the therapeutic drug dose which had four levels as follows: $5 \mathrm{mg} / \mathrm{kg}, 10 \mathrm{mg} / \mathrm{kg}, 20 \mathrm{mg} / \mathrm{kg}, 40 \mathrm{mg} / \mathrm{kg}$ body weight.

\section{Interventions}

Picroside II (CAS No.: 39012-20-9, purity> 98\%, molecular weight: 512) provided by Tianjin Kui Green pharmaceutical company, was diluted to $1 \%$ with normal saline. According to the orthogonal table of $\left[\mathrm{L}_{16}\left(4^{5}\right)\right]$, the rats were intraperitoneally injected at different ischemic time with picroside II of different doses. Rats in the sham group and experimental group were synchronously injected intraperitoneally the same amount of physiological saline.

\section{Specimen collection}

The rats were anesthetized by injecting intraperitoneally $10 \%$ chloral hydrate $(0.3 \mathrm{ml} / \mathrm{kg})$ after treatment for $24 \mathrm{~h}$, then opening the chest and collecting the blood through the heart and centrifugating at $4000 \mathrm{r} / \mathrm{min}$ for $10 \mathrm{~min}$ separate serum $2 \mathrm{ml}$ storing at $-20^{\circ} \mathrm{C}$. Then the rats were perfused immediately with normal saline $200 \mathrm{ml}$ and removed the brain completely, cut olfactory bulb and prefrontal brain tissue. The $500 \mathrm{mg}$ brain tissue of ischemia area was cut from the optic chiasm (Bregma $0.00 \mathrm{~mm}$ ) backward and set in a precooling mortar to grind to the powder and added the cell lysis buffer according to the proportion of 1:4 (500 $\mu$ l lysis buffer $+5 \mu$ l PMSF, No. P0013, Beyotime Institute of Biotechnology) and homogenized with ultrasonic waves to centrifuged (Eppendorf 5801, Germany) $12000 \mathrm{r} / \mathrm{min}$ for $10 \mathrm{~min}$ at $4^{\circ} \mathrm{C}$, then

Table 1. $\left[\mathrm{L}_{16}\left(4^{5}\right)\right]$ Orthogonal design grouping

\begin{tabular}{|l|l|l|l|l|}
\hline Dose & $\begin{array}{l}\text { Ischemia } \\
\mathbf{1 . 0 h}(\mathbf{A} 1)\end{array}$ & $\begin{array}{l}\text { Ischemia } \\
\mathbf{1 . 5 h}(\mathbf{A} 2)\end{array}$ & $\begin{array}{l}\text { Ischemia } \\
\mathbf{2 . 0 h}(\mathbf{A 3})\end{array}$ & $\begin{array}{l}\text { Ischemia } \\
\mathbf{2 . 5 h}(\mathbf{A} 4)\end{array}$ \\
\hline $5 \mathrm{mg} / \mathrm{kg}(\mathrm{B} 1)$ & $1.0 \times 5$ & $1.5 \times 5$ & $2.0 \times 5$ & $2.5 \times 5$ \\
\hline $10 \mathrm{mg} / \mathrm{kg}(\mathrm{B} 2)$ & $1.0 \times 10$ & $1.5 \times 10$ & $2.0 \times 10$ & $2.5 \times 10$ \\
\hline $20 \mathrm{mg} / \mathrm{kg}(\mathrm{B} 3)$ & $1.0 \times 20$ & $1.5 \times 20$ & $2.0 \times 20$ & $2.5 \times 20$ \\
\hline $40 \mathrm{mg} / \mathrm{kg}(\mathrm{B} 4)$ & $1.0 \times 40$ & $1.5 \times 40$ & $2.0 \times 40$ & $2.5 \times 40$ \\
\hline
\end{tabular}

separating the supernatant. The concentration of the protein was assayed by $\mathrm{BCA}$ method, stored at $-20^{\circ} \mathrm{C}$.

\section{Detection indexes}

The level of MDA and the activity of SOD in serum or brain homogenate were determined by thiobarbituric acid assay and xanthine oxidase assay respectively. According to the instruction of the kit, serum or brain homogenate was centrifuged after redissolved at room temperature. $100 \mu \mathrm{l}$ supernatant was taken for the determination of the absorbance values at the wavelength of $532 \mathrm{~nm}$ (MDA) and $550 \mathrm{~nm}$ (SOD) with UV spectrophotometer (Beckmann DU640, USA) to calculate the content of MDA $(\mathrm{mmol} / \mathrm{L})$ and the activity of SOD $(\mathrm{U} / \mathrm{ml})$.

\section{Statistical analysis}

The statistical software of SPSS 17.0 edition was used for statistical analysis. According to the different levels of ischemia time and dose, as well as the effect of the interaction between ischemia time and dose to indicators determined, the optimized composition of the therapeutic dose and time window was concluded.

\section{Results}

\section{Results of detection}

In sham-operated group, in serum the content of MDA was significantly lower than in brain $(t=4.09, P<0.01)$, and the activity of SOD was significantly higher than in brain $(t=9.33, P<0.01)$. The content of MDA in serum and brain of in model group was significantly increased, while the activity of SOD was significantly reduced than those of sham group $(t=12.32-43.86, P<0.01)$. The content of MDA in serum and brain tissue of treatment group were significantly lower, and the activity of SOD activity was significantly higher than those of model group ( $t=3.88$ to 12.76, $P<0.01)$. Table 2-3.

\section{- Variance Analysis of MDA content}

Effects of different levels of factor A (time) on the content of MDA in serum showed significant differences in cerebral ischemia $(P<0.01)$, but effects of factor B (dose) and factor C (time-dose interaction) showed no significant differences $(P>0.05)$. Different levels of administration time (therapeutic time window) had sig- 
Table 2. The detecting results of MDA and SOD

\begin{tabular}{|l|l|l|l|l|l|}
\hline Groups & $\mathbf{n}$ & $\begin{array}{l}\text { Serum MDA } \\
(\mathbf{m m o l} / \mathbf{L})\end{array}$ & $\begin{array}{l}\text { Brain MDA } \\
(\mathbf{m m o l} / \mathbf{L})\end{array}$ & $\begin{array}{l}\text { Serum SOD } \\
(\mathbf{U} / \mathbf{L})\end{array}$ & $\begin{array}{l}\text { Brain SOD } \\
(\mathbf{U} / \mathbf{L})\end{array}$ \\
\hline Sham group & 5 & $2.53 \pm 0.25$ & $6.36 \pm 0.68$ & $92.51 \pm 6.45$ & $40.86 \pm 4.76$ \\
\hline Model group & 5 & $4.38 \pm 0.56^{\mathrm{a}}$ & $9.60 \pm 0.82^{\mathrm{a}}$ & $62.43 \pm 473^{\mathrm{a}}$ & $25.44 \pm 3.29^{\mathrm{a}}$ \\
\hline Treatment group & 16 & $3.34 \pm 0.78^{\mathrm{b}}$ & $7.61 \pm 1.00^{\mathrm{b}}$ & $82.23 \pm 7.70^{\mathrm{b}}$ & $32.13 \pm 6.11^{\mathrm{b}}$ \\
\hline
\end{tabular}

${ }^{a}$ Compared with sham, $t=12.32 \sim 43.86, P<0.01$;

${ }^{\mathrm{b}}$ Compared with model group, $t=3.88 \sim 12.76, P<0.01$

Table 3: $\left[\mathrm{L}_{16}\left(4^{5}\right)\right]$ orthogonal layout and the detection results

\begin{tabular}{|c|c|c|c|c|c|c|c|c|c|}
\hline \multirow[t]{2}{*}{ Test no. } & \multicolumn{5}{|c|}{ Rank NO. } & \multirow{2}{*}{$\begin{array}{l}\text { Serum } \\
\text { MDA }\end{array}$} & \multirow{2}{*}{$\begin{array}{l}\text { Brain } \\
\text { MDA }\end{array}$} & \multirow{2}{*}{$\begin{array}{l}\text { Serum } \\
\text { SOD }\end{array}$} & \multirow{2}{*}{$\begin{array}{l}\text { Brain } \\
\text { SOD }\end{array}$} \\
\hline & $\mathrm{A}$ & B & $\mathrm{C}$ & $\mathrm{D}$ & $E$ & & & & \\
\hline 1 & 1 & 1 & 1 & 1 & 1 & 2.27 & 7.62 & 76.73 & 30.76 \\
\hline 2 & 1 & 2 & 2 & 2 & 2 & 2.58 & 7.44 & 82.93 & 31.45 \\
\hline 3 & 1 & 3 & 3 & 3 & 3 & 3.11 & 7.30 & 84.52 & 32.91 \\
\hline 4 & 1 & 4 & 4 & 4 & 4 & 3.16 & 7.54 & 81.82 & 34.62 \\
\hline 5 & 2 & 1 & 2 & 3 & 4 & 3.34 & 7.19 & 80.50 & 32.00 \\
\hline 6 & 2 & 2 & 1 & 4 & 3 & 2.61 & 6.81 & 88.22 & 38.26 \\
\hline 7 & 2 & 3 & 4 & 1 & 2 & 2.32 & 6.06 & 98.24 & 39.94 \\
\hline 8 & 2 & 4 & 3 & 2 & 1 & 2.73 & 6.22 & 80.28 & 33.41 \\
\hline 9 & 3 & 1 & 3 & 4 & 2 & 3.86 & 7.16 & 72.53 & 37.69 \\
\hline 10 & 3 & 2 & 4 & 3 & 1 & 3.13 & 6.39 & 87.40 & 38.83 \\
\hline 11 & 3 & 3 & 1 & 2 & 4 & 3.09 & 8.20 & 97.78 & 38.57 \\
\hline 12 & 3 & 4 & 2 & 1 & 3 & 4.05 & 8.70 & 81.25 & 31.58 \\
\hline 13 & 4 & 1 & 4 & 2 & 3 & 4.93 & 8.49 & 79.30 & 22.39 \\
\hline 14 & 4 & 2 & 3 & 1 & 4 & 3.82 & 8.56 & 76.34 & 27.23 \\
\hline 15 & 4 & 3 & 2 & 4 & 1 & 3.88 & 8.30 & 76.07 & 25.36 \\
\hline 16 & 4 & 4 & 1 & 3 & 2 & 4.51 & 9.70 & 71.74 & 19.15 \\
\hline $\mathbf{I}$ & 11.12 & 14.40 & 12.48 & 12.46 & 12.01 & 53.39 & 121.68 & 1315.65 & 514.15 \\
\hline II & 11.00 & 12.14 & 13.85 & 13.33 & 13.27 & & & & \\
\hline III & 14.13 & 12.40 & 13.52 & 14.09 & 14.70 & & & & \\
\hline IV & 17.14 & 14.45 & 13.54 & 13.51 & 13.41 & & & & \\
\hline SS & 6.37 & 1.17 & 0.27 & 0.34 & 0.91 & & & & \\
\hline
\end{tabular}

nificant impact on the content of MDA in serum, while different levels of dose no significance. And there was no significant interaction between administration time and dose. Least significant differences (LSD) method for the pairwise comparison of each group showed that the content of MDA in serum had significant differences between administration (ischemia) time 1.0h (A1) and 2.5h (A4), 1.5h (A2) and 2.5h (A4) $(P<0.05)$, but no significant differences between other pairwise comparisons $(P>0.05)$; and the content of MDA in serum had no significant differences between pairwise comparisons of dose $(P>0.05)$. From the principle of lowest therapeutic dose with longest time window, the optimized composition was A2B2, that is to say the best therapeutic dose and time window of picroside II in cerebral ischemic injury was ischemia $1.5 \mathrm{~h}$ with $10 \mathrm{mg} / \mathrm{kg}$ body weight by intraperitoneal injection.

Different levels of ischemic time or therapeutic time window (factor A) had significant effect on the content of MDA in brain $(P<0.01)$, but different levels of dose (factor B) had no significant impact $(P>0.05)$. And there was no significant interaction between administration time and dose (factor $C)(P>0.05)$. LSD for pairwise comparisons showed that the content of MDA in brain had significant differences between administration (ischemia) time 1.0h (A1) and 2.5h (A4), 1.5h (A2) and 2.5h (A4) $(P<0.05)$, but no significant differences between other pairwise comparisons of adminstration time $(P>0.05)$ and no significant differences between pairwise comparisons of dose $(P>0.05)$. So that the optimized composition shoul be A2B2, ie. the best therapeutic dose and time window of picroside II in cerebral ischemic injury was ischemia $1.5 \mathrm{~h}$ with $10 \mathrm{mg} / \mathrm{kg}$ body weight.

\section{- Variance Analysis of SOD activity}

Effects of different levels of factor A (time) and factor B (dose) on the activity of SOD in serum showed significant differences in cerebral ischemia $(P<0.01)$, but effects of factor $\mathrm{C}$ (time-dose interaction) showed no significant differences $(P>0.05)$. Different levels of ischemic time (therapeutic time window) and dose impacted significantly on the activity of SOD in serum, while administration time-dose interaction was of no significant effect $(P>0.05)$. LSD for pairwise comparisons showed that the activity of SOD in serum had significant differences between administra- 
Table 4. Variance Analysis of MDA content

\begin{tabular}{|l|l|l|l|l|l|l|l|l|l|l|}
\hline $\begin{array}{l}\text { Sources of vari- } \\
\text { ation }\end{array}$ & $\mathbf{S S}_{\text {Serum }}$ & $\mathbf{d f}$ & $\mathbf{M S}$ & $\boldsymbol{F}$ & $\boldsymbol{P}$ & $\mathbf{S S}_{\text {Brain }}$ & $\mathbf{d f}$ & $\mathbf{M S}$ & $\boldsymbol{F}$ & $\boldsymbol{P}$ \\
\hline Ischemic time & 6.37 & 3 & 2.12 & 10.20 & 0.01 & 9.71 & 3 & 3.24 & 12.60 & 0.01 \\
\hline Dose & 1.17 & 3 & 0.39 & 1.87 & 0.24 & 1.21 & 3 & 0.40 & 1.57 & 0.29 \\
\hline Time $\times$ Dose & 0.27 & 3 & 0.09 & 0.43 & 0.74 & 2.57 & 3 & 0.86 & 3.33 & 0.10 \\
\hline Error & 1.25 & 6 & 0.21 & & & 1.54 & 6 & 0.26 & & \\
\hline
\end{tabular}

Table 5. Variance Analysis of SOD activity

\begin{tabular}{|l|l|l|l|l|l|l|l|l|l|l|}
\hline $\begin{array}{l}\text { Sources of vari- } \\
\text { ation }\end{array}$ & $\mathbf{S S}_{\text {Serum }}$ & $\mathbf{d f}$ & $\mathbf{M S}$ & $\boldsymbol{F}$ & $\boldsymbol{P}$ & $\mathbf{S S}_{\text {Brain }}$ & $\mathbf{d f}$ & $\mathbf{M S}$ & $\boldsymbol{F}$ & $\boldsymbol{P}$ \\
\hline Ischemic time & 273.42 & 3 & 91.14 & 5.09 & 0.04 & 435.32 & 3 & 145.11 & 28.64 & 0.01 \\
\hline Dose & 347.02 & 3 & 115.67 & 6.46 & 0.03 & 62.08 & 3 & 20.69 & 4.08 & 0.07 \\
\hline Time $\times$ Dose & 162.10 & 3 & 54.03 & 3.02 & 0.12 & 32.34 & 3 & 10.78 & 2.13 & 0.20 \\
\hline Error & 107.46 & 6 & 17.91 & & & 30.40 & 6 & 5.07 & & \\
\hline
\end{tabular}

tion (ischemia) time $1.5 \mathrm{~h}(\mathrm{~A} 2)$ and $2.5 \mathrm{~h}(\mathrm{~A} 4), 2 \mathrm{~h}(\mathrm{~A} 3)$ and $2.5 \mathrm{~h}$ (A4) $(P<0.05)$, but no significant differences between other pairwise comparisons of administration time $(P>0.05)$; and there were significant differences between administration dosage of $5 \mathrm{mg}$ (B1) and 20mg (B3), 20mg(B3) and 40mg(B4) $(P<0.05)$, but no significant differences between other pairwise comparisons of administration dosage $(P>0.05)$. So that the optimized composition should be A2B3, that is to say the best therapeutic dose and time window of picroside II in cerebral ischemic injury was ischemia $1.5 \mathrm{~h}$ with $20 \mathrm{mg} / \mathrm{kg}$ body weight.

Ischemic time or therapeutic time window (factor A) had significant effect on the activity of SOD in brain $(P<0.01)$, but different levels of dose (factor B) and time-dose interaction (factor $C$ ) had no significant impact $(P>0.05)$. LSD for pairwise comparisons showed that the activity of SOD in brain had no significant differences between administration (ischemia) time 1.0h (A1) and 1.5h (A2), 1.5h (A2) and 2.0h (A3), 1.5h(A2) and 2.5h(A4), $2.0 \mathrm{~h}(\mathrm{~A} 3)$ and $2.5 \mathrm{~h}(\mathrm{~A} 4)(P>0.05)$, but there were significant differences between other pairwise comparisons of administration time $(P<0.05)$. There were significant differences between administration dosage of $10 \mathrm{mg}$ (B2) and 40mg (B4), 20mg (B3) and 40mg (B4) $(P<0.05)$, but no significant differences between other pairwise comparisons of administration dosage $(P>0.05)$. From the principle of lowest therapeutic dose with longest time window, the optimized composition was A2B3, that is to say the best therapeutic dose and time window of picroside in cerebral ischemic injury was ischemia $1.5 \mathrm{~h}$ with $20 \mathrm{mg} / \mathrm{kg}$ body weight by intraperitoneal injection.

\section{Discussion}

Previous studies found that progesterone has neuroprotective effects on cerebral ischemic damage. Progesterone can improve the activity of SOD and GSHPx in hypoxic-ischemic brain to scavenge oxygen free radicals[17], as well as reduce the intracellular $\mathrm{Ca}^{2+}$ and influence the function of amino acid neurotransmitter systems [18], and restoring inositol triphosphate in cerebral ischemia area [19]. Many active ingredients of traditional Chinese medicine such as ginkgolide B [20,21] and ginkgolide N [22,23] can significantly reduce cerebral infarction and improve the activity of SOD and reduce the content of MDA in brain, inhibit neuronal apoptosis induced by mitochondrial pathway, thus playing an important role in protective effect on ischemia-reperfusion brain injury. As the main bioactive component of Picrorbiza, iridoid glycosides compounds has anti-inflammatory and antioxidation functions[24]. Animal experiments showed that picroside II can improve the antioxidant capacity of brain tissue and reduce the oxidative damage induced by cerebral ischemia-reperfusion, thus improving neurobehavioral functions of rats[25,26]. Cell culture experiments confirmed that Picrorbiza II has an important role to protect PC12 cell damege casused by $\mathrm{H}_{2} \mathrm{O}_{2}[10-11]$ and L-02 cell injury induced by oxidative stress[27]. which may be related to the ability of scavenging oxygen free radicals directly and enhancing cell itself the function of antioxidant system, as well as the function of anti-lipid peroxidation.

The content of MDA can reflect the changes of free radicals in some extent while SOD can reflect the changes of the activity of antioxidant enzymes in cerebral ischemic injury in vivo. According to $\left[\mathrm{L}_{16}\left(4^{5}\right)\right]$ orthogonal design grouping in this experiment, the four dose of picroside II $(5 \mathrm{mg} / \mathrm{kg}, 10 \mathrm{mg} / \mathrm{kg}, 20 \mathrm{mg} / \mathrm{kg}$ and $40 \mathrm{mg}$ $/ \mathrm{kg}$ ) were all given at the four time points of ischemia $1 \mathrm{~h}, 1.5 \mathrm{~h}$, $2 \mathrm{~h}$ and $2.5 \mathrm{~h}$. The detecting results of MDA and SOD showed that different levels of administration time and dose have significant influence on the therapeutic effect of picroside II. The best combination of different detection indexes was variant. From the principle of lowest therapeutic dose with longest time window, the optimized composition were A2B2 and A2B3, that is to say the best therapeutic dose and time window of picroside II in cerebral ischemic injury was ischemia $1.5 \mathrm{~h}$ with $10-20 \mathrm{mg} / \mathrm{kg}$ body weight. Because the mechanism of cerebral ischemic injury is very complicated and only four indexes were observed in this experiment, the results could not possibly all be right. In further experiments, the golden evaluating indexes need to be further studied to explore the certain effect and mechanism and the best therapeutic time window and the best therapeutic dose of picroside II.

\section{Acknowledgements}

This article was supported by the National Natural Science Foundation of China (81041092) and Shandong Province Natural Science Foundation (ZR2011HM050).

\section{References}

[1]. Yuan Y, Yang JQ, Zhou QX. Relationship between SOD expression and free radical level in neurodegeneration induced by ischemia-reperfusion in 
mouse. Basic Clin Med, 2011, 31(11), 1229-1233.

[2]. Amemiya S, Kamiya T, Nito C, Inaba T, Kato K, Ueda M, Shimazaki K, Katayama Y. Anti-apoptotic and neuroprotective effects of edaravone following transient focal ischemia in rats. Eur J Pharmacol 2005, 516(2):125-130.

[3]. Cejas P, Casado E, Belda-Iniesta C, De Castro J, Espinosa E, Redondo A, Sereno M, García-Cabezas MA, Vara JA, Domínguez-Cáceres A, Perona $\mathrm{R}$, González-Barón M. Implieations of oxidative stress and cell membrane lipid peroxidation in human cancer (Spain).Cancer Cuases Contor, 2004,15(7):707-719.

[4]. Liu Y, Li C P, Zhu L. Oxidative Stress, Lipid peroxidation and liver cell apoptosis play an important role in non-alcoholic fatty liver disease. Med Recap, 2008,14(10):1468-1470.

[5]. Tomatsuri N, Yoshida N, Takagi T, Katada K, Isozaki Y, Imamoto E, Uchiyama K, Kokura S, Ichikawa H, Naito Y, Okanoue T. Edavavone, a newly developed radical scavenger protects against ischemia-reperfusion injury of the small intestine in rats. Int J Mol Med, 2004,13(1): 105-107.

[6]. Sun L, Long ZJ, Zhang DF, Liu JL, Lu H, Yu QQ. Protective Effects of Sapindoside on Experimental Myocardial Ischemia in Rat. Chin J Exp Tradit Med Form, 2011, 17(1):110-112.

[7]. Lv SX, Jia HL, Chen CG, Sun LH, Xu CQ. The protective effect of propylgallate injection on acute cerebral ischemic reperfusion injury. J Apoplexy and Nervous Diseases, 2011, 28(10): 935-937.

[8]. Gargouri B, Mansour RB, Abdallah FB, Elfekih A, Lassoued S, Khaled H. Protective effect of quercetin against oxidative stress caused by dimethoate in human peripheral blood lymphocytes. Lipids Health Dis, 2011,10(2):149.

[9]. Li P, Matsunaga K, Yamakuni T, Ohizumi Y. Picrosides I and II, selective enhancers of the mitogen-activated protein kinase-dependent signaling pathway in the action of neuritogenic substances on PC12D cells. Life Sci, 2002, 71(15):1821-1835.

[10]. Tao YW, Liu JW, Wei DZ, Su W, Zhou WY. Protective effect of picroside-II on the demage of cultured PC12 cell in vitro. Chin J Clin Pharmacol Ther, 2003,8(1):27-30.

[11]. Guo MC, Cao Y, Liu JW. Protective effects of picroside II on glutamate injury of PC12 cells. Chin J Clin Pharmacol Ther, 2007,12(4):440-443.

[12]. Li Z, Li Q, Guo YL, Qin LH, Luan LJ. Interference effect of picroside II on cerebral ischemia reperfusion injury in rats. Acta Anatomica Sinica, 2010, 41(1):9-12.

[13]. Li Z, Xu XY, Li Q, Zhang MZ, Shen W. Protective mechanisms of picroside on AQP4 in rat model of MCAO/R. Neural Regen Res, 2010, 5(6):411416.

[14]. Li Q, Li Z, Xu XY, Guo YL, Du F. Neuroprotective properties of picroside II in rat model of focal cerebral ischemia. Int J Mol Sci, 2010, 11(11):4580-
4590 .

[15]. Pei HT, Su X, Zhao L, Li HY, Guo YL, Zhang MZ, Xin H. Primary study for the therapeutic dose and Time window of picroside II in treating cerebral ischemic injury in rats. Int J Mol Sci, 2012, 13(2):2551-2562.

[16]. Márquez-Martín A, Jiménez-Altayó F, Dantas AP, et al. Middle cerebral artery alterations in a rat chronic hypoperfusion model. J Appl Physiol, 2012,112(3):511-518.

[17]. Li DL, Wang XY, Han H, Zhao HG. Effect of progesterone on the activity of SOD and GSH-Px in brain tissue with hypoxic-ischemic encepholopathy in newborn rats. Chin Pharmacol Bull, 2007,23(2):276-277.

[18]. Moralí G, Letechipía-Vallejo G, López-Loeza E, Montes P, Hernández-Morales L, Cervantes M.Post ischemic administration of progesterone in rats exerts neuroprotective effects on the hippocampus. Neurosic Lett, 2005, 382 (3):286-290.

[19]. Chen HB, Chen TP, Hou GF, Chen XY, Cheng SH, Chen XR. Neuroprotection of progesterone against cerebral ischemia-reperfusion injury on rats and the effect on IP3 content. Acta Universitatis Medicinalis Anhui, 2012,47(5):511-512.

[20]. Huang JY, Sun JN, Mei SC, Huang JM. Protective effects of ginkgolide B on cerebral ischemia reperfusion injury in rats. Chin Pharmacol Bull, 2008, 24(2):269-272.

[21]. Lin Y, Cui HX, Zhao XM, Sun C. Protective effects of Ginkgolide B on cerebral ischemia reperfusion injury in rats. Chin J Pharmacol Toxicol, 2012, 26(3):430-431.

[22]. Zhang XT, Liang J, Liu HX, Han GC, Ma SW. Protective Effects of Ginkgolide $\mathrm{N}$ on Focal Cerebral Ischemia Reperfusion Injury in Rats. Chin J Exp Tradit Med Form, 2012,18(1):141-144

[23]. Zhang XT, Ma SW, Wu QY, Liu Y, He SJ, Suo QL. Protective effects of ginkgolide non focal cerebral ischemia-reperfusion injury in rats. Lishizhen Medicine and Materia Medica Research, 2012, 23(4):797-800.

[24]. Li P, Kimihiro M, Yasushi O. Nerve growth factor potentiating compounds from rhizoma. Biol Pharm Bull, 2000,23(7):890-892.

[25]. Zhao DM, Zhang ZQ, Duan YX, Zhang BZ, Liu QS. Neuroprotective effect of picroside II on cerebral ischemia-reperfusion injury in rats. J Int Pharm Res, 2010,37(6): 461-468.

[26]. Sun L, Li XD, Wang L, Qin LH, Guo YL, Zhou Z. The Anti-oxidant effect and the possible mechanism of picroside II in cerebral ischemia reperfusion injury in rats. Neural Regen Res, 2011, 6(15):1141-1146.

[27]. Gu W, Fan XJ, Wu J, Niu ZhQ. Protective effect of Picroside II against $\mathrm{H}_{2} \mathrm{O}_{2}$-induced damage In L-02 cells. World Chinese Journal of Digestology, 2008, 16(29): 3274-3278 